\title{
GOSPODARCZE DOKONANIA II RZECZYPOSPOLITEJ - TRADYCJE I WYZWANIA
}

\author{
Wojciech Morawski
}

Dttp://orcid.org/0000-0002-0228-3046

Szkoła Główna Handlowa

\author{
ABSTRACT \\ ECONOMIC ACHIEVEMENTS OF INTERWAR POLAND: TRADITIONS \\ AND CHALLENGES
}

The economic policy of Interwar Poland was shaped by two outstanding personalities - Władysław Grabski and Eugeniusz Kwiatkowski. Grabski represented the tradition of liberal economic policy, macroeconomic balance and openness. Kwiatkowski has become a symbol of economic self-sufficiency, independence from outside world and of statism. Interwar Poland faced four big challenges: unification, macroeconomic stabilisation, capitalisation and modernisation, and it succeeded in all those fields. However, the problem of social and national integrity remained unsolved.

Keywords: modernisation, economic policy, Interwar Poland.

Słowa kluczowe: modernizacja, polityka gospodarcza, II Rzeczpospolita.

Celem opracowania jest przegląd dokonań II Rzeczypospolitej na polu gospodarczym z dwóch punktów widzenia: tradycji polityki gospodarczej, jaką Polska międzywojenna po sobie pozostawiła, i wyzwań, którym musiała sprostać.

\section{TRADYCJE POLSKIEJ POLITYKI GOSPODARCZEJ}

Tradycje polskiej polityki gospodarczej nie są zbyt bogate, na pewno skromniejsze niż tradycje polityczne. Do czasu rozbiorów trudno było mówić o polskiej polityce gospodarczej. W pierwszej połowie XIX wieku pojawia się ważna, ale dość jednowymiarowa postać Ksawerego Druckiego-Lubeckiego. Później, wobec braku 
własnego państwa, Polacy nie brali udziału w wielkich debatach ekonomicznych XIX stulecia. Ominął nas w ten sposób zarówno spór między zwolennikami szkoły klasycznej i szkoły historycznej, jak i spór między zwolennikami wolnego handlu i protekcjonizmu. W XX wieku nie wzbogaciły tradycji doświadczenia czasów PRL, prowadzona wówczas polityka gospodarcza skażona była bowiem piętnem braku suwerenności. W tej sytuacji szczególnego znaczenia nabrały czasy II Rzeczypospolitej. Tradycje polityki gospodarczej tej epoki zostały zdominowane przez dwie postaci: Władysława Grabskiego i Eugeniusza Kwiatkowskiego. Działali oni w innych okresach i w radykalnie odmiennych warunkach. Jedną z cech pamięci historycznej jest jednak to, że zjawiska niewspółczesne sobie stawia obok siebie po to, by skonfrontować je na gruncie ponadczasowych wartości z pominięciem kontekstu chronologicznego.

Władysław Grabski działał w latach 20., kiedy świat po kataklizmie wielkiej wojny próbował powrócić do liberalnej polityki gospodarczej uważanej za oczywisty standard oraz do równowagi finansowej. Wydawało się przy tym, że uda się odbudować przedwojenną otwartość gospodarek krajowych na świat. Grabski w związku z tym symbolizuje tradycje liberalnej polityki gospodarczej, równowagi makroekonomicznej, otwartości na świat i na kapitał zagraniczny. Wyznawał także dominację podejścia ekonomicznego i finansowego nad inżynierskim, wiarę w prywatną przedsiębiorczość, w rynek i jego zdolności samoregulacyjne.

Aktywność Eugeniusza Kwiatkowskiego przypadła przede wszystkim na drugą połowę lat 30. Doświadczenie wielkiego kryzysu zachwiało zaufanie do samoregulacyjnych zdolności rynku. Ratunek widziano w aktywności gospodarczej państwa, czy to $\mathrm{w}$ formie interwencjonizmu, czy etatyzmu. Świat odzyskał przedkryzysowy poziom produkcji przemysłowej, ale stało się to w sytuacji, kiedy wolumen handlu światowego był znacznie poniżej przedkryzysowego. Oznaczało to, że każdy kraj radził sobie z kryzysem sam, nie można było mówić o wspólnych działaniach gospodarki światowej jako całości. Narastały tendencje protekcjonistyczne czy wręcz autarkiczne. Międzynarodowy system finansowy uległ daleko posuniętej dezintegracji, a w poszczególnych krajach umacniały się systemy reglamentacyjne. W tej sytuacji Kwiatkowski stał się symbolem samowystarczalności gospodarczej, niezależności od świata, etatyzmu, dominacji sfery realnej inżynierskiej nad ekonomiczną i finansową.

Warto prześledzić losy obu patronów w późniejszych epokach. W pierwszych latach PRL Kwiatkowski był czynnym politykiem, a industrializacja stanowiła główny cel polityki gospodarczej kraju. Przewaga tradycji Kwiatkowskiego nad Grabskim była oczywista. W czasach stalinowskich wszelkie odwołania do II Rzeczypospolitej były niemożliwe, ale ogólny pogląd, że światowa gospodarka kapitalistyczna dożywa swych dni, a przyszłość należy do zamkniętych, silnie uprzemysłowionych gospodarek krajowych przybliżał plan 6-letni do tradycji COP-owskiej. Po 1956 roku zaczęła się stopniowa rehabilitacja dorobku II RP, przy czym reakcją na nachalną propagandę była idealizacja tego okresu. Kwiatkowski doczekał się uznania szybciej od Grabskiego. Jako uczeń szkoły podstawowej w latach 60. pamiętam zdjęcia Kwiatkowskiego w (dość okropnych) ówczesnych podręcznikach do historii. Zdjęć 
Grabskiego nie pamiętam. W okresie socjalizmu inżynierskie, rzeczowe podejście do spraw gospodarczych dominowało nad myśleniem w kategoriach równowagi makroekonomicznej czy też miejsca w otwartej gospodarce światowej. Charakterystyczne były pisane wówczas syntezy dziejów gospodarczych II Rzeczypospolitej' Rozdziały o finansach zawsze umieszczane były na końcu, za przemysłem, rolnictwem, handlem itd. Sprawy finansowe wyraźnie postrzegane były jako usługowe wobec sfery realnej - choć w pracach monograficznych ci sami autorzy doceniali rolę równowagi finansowej².

Klęska industrializacji w latach 70. i zwrot monetarystyczny, który dokonał się na świecie u schyłku tej dekady, stopniowo odwracały proporcje. Pierwsza dekada III Rzeczypospolitej upłynęła pod znakiem rosnącej popularności Władysława Grabskiego, do którego chętnie porównywano reformy Balcerowicza³. Uroczyście obchodzono rocznice związane z Grabskim (np. w jego macierzystej uczelni SGGW-AR w 2004 r.). Pamięć o Kwiatkowskim nie zaginęła, ale miała raczej lokalny charakter. Jej ośrodkami były miasta COP-u i Gdynia. Przewaga Grabskiego nad Kwiatkowskim trwała do kryzysu 2008 roku, jeszcze publikacje z okazji 90-lecia niepodległości dawały jej wyraz 4 . Potem jednak równowaga makroekonomiczna znów zaczęła tracić na znaczeniu na rzecz sfery realnej i zaczął się renesans popularności Kwiatkowskiego. Dziś jest on zdecydowanie górą, do niego najchętniej odwołują się aktualne władze, z Mateuszem Morawieckim na czele.

\section{WYZWANIA}

W ciągu krótkiego okresu 20 lat państwo polskie musiało sprostać kilku wielkim wyzwaniom na polu gospodarczym. Stanęło przed nimi w warunkach dalece niesprzyjających, ponieważ dwudziestolecie niepodległości przypadło, z punktu widzenia światowej koniunktury gospodarczej, na czas trudny. Wielka wojna pozostawiła po sobie ogromne nierównowagi finansowe w skali całego świata. Długi wojenne państw ententy wobec Stanów Zjednoczonych z jednej strony, a ogromne reparacje wojenne nałożone na pokonanych $\mathrm{z}$ drugiej strony były tak przytłaczające,

${ }^{1}$ Przede wszystkim czterotomowe dzieło: Z. Landau, J. Tomaszewski, Gospodarka Polski międzywojennej, Warszawa 1967-1989. Zob. także: Problemy gospodarcze Drugiej Rzeczypospolitej, red. I. Ko strowicka, Warszawa 1989.

${ }^{2}$ Choć w pracach monograficznych ci sami autorzy doceniali kluczową rolę równowagi finansowej. Wymienić tu trzeba przede wszystkim pracę o rządzie Władysława Grabskiego: J. To maszewski, Stabilizacja waluty $w$ Polsce. Z badań nad polityka gospodarcza rzadu polskiego przed zamachem majowym, Warszawa 1961 czy książkę o planie stabilizacyjnym: Z. L a n d a u, Plan stabilizacyjny 19271930. Geneza, założenia, wyniki, Warszawa 1963.

${ }^{3}$ Por. np. Od Grabskiego do Balcerowicza. Systemy pieniężne w gospodarce polskiej, red. S. Kow a 1, Poznań 1997.

${ }^{4}$ Na przykład W. Morawski, Od marki do złotego. Historia finansów Drugiej Rzeczypospolitej, Warszawa 2008. 
że niemożliwe stało się przywrócenie normalnych, zrównoważonych relacji handlowych. Dlatego podejmowane w latach 20. próby powrotu do „normalnej”, czyli przedwojennej polityki gospodarczej, opartej na zasadach liberalizmu gospodarczego, złotej waluty i względnej łatwości przekraczania granic przez towary, ludzi i kapitały, nie tylko nie zakończyły się sukcesem, ale doprowadziły do najgłębszego w dziejach gospodarki rynkowej kryzysu lat 30 . Kryzys udało się po kilku latach przezwyciężyć, ale dokonało się to kosztem dalszego załamania wymiany międzynarodowej i jednocześnie zamykania się poszczególnych gospodarek narodowych we własnych, dążących do samowystarczalności systemach. W sumie na dwadzieścia lat niepodległości przypadało najwyżej kilka (1926-1929 i 1936-1939) lat dobrej koniunktury. Z takimi okolicznościami zewnętrznymi przychodziło się mierzyć gospodarce II Rzeczypospolitej, a entuzjazm, związany z „radością z odzyskanego podwórka", tylko częściowo łagodził sytuację. Przyjrzyjmy się zatem kolejno wielkim wyzwaniom, którym musiała sprostać gospodarka polska, oraz odpowiedziom, jakich na te wyzwania udzieliła.

\section{Unifikacja}

Scalenie kraju po ponadstuletnich zaborach przyniosło wiele problemów. Niektóre z nich były błahe, na przykład w Galicji obowiązywał lewostronny ruch pociągów, w pozostałych zaborach prawostronny. Tego typu różnice były łatwe do usunięcia, choć wymagały przeróbek infrastruktury. Bardziej skomplikowanym wyzwaniem była na przykład unifikacja walutowa. W obiegu znajdowały się bowiem waluty państw zaborczych, marki polskie emitowane przez utworzoną w 1917 roku w Warszawie przez niemieckie władze okupacyjne Polską Krajową Kasę Pożyczkową, ostruble emitowane przez Niemcy na użytek innych okupowanych terenów rosyjskich, ukraińskie griwny i karbowańce oraz liczne „waluty” emitowane przez władze lokalne. Wszystkie one podlegały procesom inflacyjnym, a ich kursy były płynne, co jeszcze bardziej pogłębiało chaos. Spośród walut będących w obiegu tylko marka polska nie była używana w żadnym innym państwie. W grudniu 1918 roku właśnie markę polską uczyniono tymczasową polską walutą i stopniowo, do 1922 roku, wycofano z obiegu inne środki płatnicze. Unifikacja waluty była przedsięwzięciem delikatnym pod względem politycznym. Przeprowadzenie jej w sposób dyskryminujący którąś z dzielnic mogło podsycić i tak silne separatyzmy. Dodatkowo utrudniał całe przedsięwzięcie fakt, że wprowadzano pieniądz z założenia tymczasowy, podlegający ponadto szybkiej deprecjacji. Już wiosną 1919 roku postanowiono bowiem, że przyszłą polską walutą po stabilizacji będzie złoty. W tej sytuacji szybką i niewywołującą konfliktów unifikację monetarną należy uznać za sukces.

Znacznie trudniejsze było ujednolicenie zasad prawnych regulujących kwestie gospodarcze i socjalne. Tylko w niektórych dziedzinach proces ten doprowadzono do pomyślnego końca. Prawo bankowe na przykład ujednolicono dopiero w 1928 roku, a i wówczas zachowano odrębne regulacje w województwie śląskim. System podatkowy pozostał zróżnicowany do końca dwudziestolecia międzywojennego. Do 
jego ujednolicenia przygotowywał się minister skarbu Gabriel Czechowicz, ale afera związana z nielegalnym finansowaniem BBWR w 1929 roku, która położyła kres jego karierze, zakończyła też próby w tej dziedzinie. Potem, podczas kryzysu, już nie wracano do tego tematu.

Co stało na przeszkodzie unifikacji prawnej? Jeśli nie miała ona w którejś z dzielnic wywołać frustracji, to nikt nie powinien stracić uprawnień już posiadanych. A to oznaczało, że powinna obowiązywać swoista „klauzula najwyższego uprzywilejowania”. Wszystkie lokalne najkorzystniejsze dla społeczeństwa rozwiązania powinny być rozszerzone na cały kraj. Polski na tego typu unifikację po prostu nie było stać. Zwłaszcza upowszechnienie w całym kraju niemieckich standardów w dziedzinie praw socjalnych byłoby posunięciem ponad $\operatorname{stan}^{5}$. Jeszcze trudniejsza była realna unifikacja gospodarcza. Świetnie rozwinięte rolnictwo zaboru pruskiego zostało odcięte od tradycyjnych rynków zbytu i wystawione na konkurencję gorszej jakości, ale znacznie tańszej produkcji z obu pozostałych zaborów. Trzeba było znaleźć nowe rynki zbytu dla śląskiego węgla i galicyjskiej ropy. Potężny przemysł włókienniczy zaboru rosyjskiego utracił tradycyjne rynki zbytu na wschodzie. Procesy dostosowawcze w tej sferze za sprawą mechanizmów rynkowych toczyły się swoim trybem, ale były bolesne.

\section{Stabilizacja makroekonomiczna}

Podczas I wojny światowej we wszystkich państwach wzrósł obieg pieniężny. Inflacyjne skutki wojny ujawniły się w pełni po jej zakończeniu, kiedy zniesiono wojenną kontrolę cen i system kartkowy. Przez wszystkie kraje Europy przeszła fala inflacji. W nielicznych, do których należała również Polska, doszła do fazy hiperinflacji. Wśród nich znalazły się państwa, które przegrały wojnę: Niemcy, Austria i Węgry. O przynależności Polski do tej grupy zadecydowała wojna 1920 roku, kiedy to wydatki wojskowe zostały, całkiem słusznie, uwolnione od wszelkiej kontroli. W pierwszej połowie lat 20. odzyskanie równowagi makroekonomicznej było zatem zadaniem numer jeden. W 1921 roku uwolniono ceny i zniesiono reglamentację handlu. Inflacja objawiała się odtąd nie tyle problemami z dostępem do towarów, ile szybkim wzrostem cen. Źródłem inflacji był, jak zawsze, deficyt budżetowy. Skuteczna reforma pieniężna musiała być zatem związana z reformą skarbową, czyli zrównoważeniem budżetu. Pierwszą poważną próbę stabilizacji podjął na przełomie 1921 i 1922 roku minister skarbu Jerzy Michalski. Próba ta została jednak obalona przez PPS, która obawiała się skutków kryzysu postabilizacyjnego. Inflacja bowiem, oprócz wad, ma też zalety: nakręca koniunkturę, zmniejsza bezrobocie (choć równocześnie godzi w poziom płac realnych), ułatwia eksport, praktycznie zabezpiecza przed groźbą bankructwa. Stabilizacja oznacza koniec tych nadzwyczajnych ułatwień. Z inflacją można zatem żyć długo. Hiperinflacja, którą ekonomiści lokują

${ }^{5}$ Na dylematy te zwrócił uwagę Paweł Grata: idem, Polityka społeczna Drugiej Rzeczypospolitej, Rzeszów 2013, s. 296-297. 
powyżej 50\% miesięcznie, nie daje już takich udogodnień. Kiedy do niej dojdzie, reformy stają się sprawą pilną.

Polska weszła w fazę hiperinflacji w drugiej połowie 1923 roku. W grudniu tego roku władzę objął rząd Władysława Grabskiego, który przeprowadził zasadnicze reformy ${ }^{6}$. Reforma skarbowa zakładała redukcję wydatków, głównie dotacji do kolei, oraz wzrost dochodów poprzez wprowadzenie mechanizmu waloryzacji zaległych podatków oraz nową daninę - podatek majątkowy. Reforma walutowa zakładała zastąpienie marki polskiej nową walutą - złotym, równym frankowi szwajcarskiemu, emitowanym przez niezależny od rządu Bank Polski S. A. Podobne reformy przeprowadzano $\mathrm{w}$ tym czasie $\mathrm{w}$ pozostałych państwach dotkniętych hiperinflacją. $\mathrm{Z}$ reguły były one wspierane finansowo z zagranicy. Polska takiego wsparcia nie uzyskała. Przeprowadziła reformy, opierając się wyłącznie na zasobach wewnętrznych. Był to oczywiście sukces, ale też nie bardzo istniało inne wyjście. W ówczesnej sytuacji politycznej Europa szukała kompromisu z Niemcami, biorąc pod uwagę możliwość rewizji ich granic wschodnich. Pomoc finansowa dla Polski uwarunkowana byłaby sugestią podjęcia rozmów z Niemcami na ten temat. Aby takich rozmów uniknąć, nie należało $\mathrm{w}$ tym momencie prosić o pieniądze.

Reformy Grabskiego zakończyły się sukcesem, ale kryzys postabilizacyjny dał o sobie znać. Pogłębiła go wojna celna z Niemcami, która wybuchła na początku 1925 roku. Choć ostatecznie przegrana przez Niemcy, postawiła ona początkowo polską gospodarkę w obliczu poważnych problemów. Latem 1925 roku załamał się złoty, w ślad za tym poszedł kryzys bankowy. Grabski odchodził z poczuciem porażki. Zaczęto mówić o „drugiej inflacji polskiej”. Okazało się, że było w tym określeniu dużo przesady. Następca Grabskiego na stanowisku ministra skarbu Jerzy Zdziechowski ustabilizował walutę na nieco niższym poziomie ${ }^{7}$, a w lutym 1926 roku powróciła dobra koniunktura. Zwieńczeniem sukcesu była druga stabilizacja ${ }^{8}$, przeprowadzona już pod rządami sanacji w 1927 roku. Tym razem Polska otrzymała dużą pożyczkę stabilizacyjną, a złoty stał się jedną z najmocniejszych walut europejskich.

Kiedy wybuchł wielki kryzys, dość powszechne w Europie były obawy, że wraz z nim powróci inflacja. Z ekonomicznego punktu widzenia obawy te były absurdalne. Kryzys nadprodukcji, który objawia się spadkiem cen, nie przekłada się automatycznie na inflację. Wręcz przeciwnie - działa deflacyjnie. Obawy przed inflacją były jednak faktem społecznym i determinowały działania władz. Stąd bardzo ostrożna i konserwatywna polityka gospodarcza sanacji'. Na spadek dochodów wywołany przez osłabienie aktywności gospodarczej rząd zareagował redukcją wydatków, choć było wiadomo, że doraźnie pogłębi kryzys. Polityka „przeczekiwania” kryzysu była

${ }^{6}$ J. Tomaszewski, Stabilizacja waluty w Polsce. Z badań nad polityka gospodarcza rzadu polskiego przed zamachem majowym, Warszawa 1961.

7 W. Moraw ski, Polityka gospodarcza rządu Aleksandra Skrzyńskiego, Warszawa 1990.

${ }^{8}$ Z. Landa u, Plan stabilizacyjny 1927-1930. Geneza, założenia, wyniki, Warszawa 1963.

${ }^{9} \mathrm{Z}$ prac poświęconych polityce rządu polskiego podczas wielkiego kryzysu warto wymienić klasyczną: Z. Knakiewicz, Deflacja polska 1930-1935, Warszawa 1967 i najnowszą: C. Leszczyńska, Polska polityka pieniężna i walutowa w latach 1924-1936 w systemie Gold Exchange Standard, Warszawa 2013. 
zgodna z dziewiętnastowiecznymi, liberalnymi zasadami. Teraz jednak nie przynosiła pożądanego rezultatu. Konserwatyzm polskiej polityki gospodarczej znalazł wyraz również w przynależności do złotego bloku - ugrupowania krajów, które mimo kryzysu nie dewaluowały swoich walut i nie zawieszały wymienialności na złoto. Blok, któremu przewodziła Francja, okazał się jednak nieskuteczny i rozpadł się w 1936 roku.

W Polsce doszło wówczas do sporu. Prezes Banku Polskiego Adam Koc uważał, że Polska powinna zawiesić wymienialność i zdewaluować złotego, dołączając do skupionego wokół Wielkiej Brytanii bloku szterlingowego. Minister skarbu Eugeniusz Kwiatkowski był zdania, że nie należy nic zmieniać poza wprowadzeniem reglamentacji dewizowej, czyli nakazu odsprzedania Bankowi Polskiemu zagranicznych dewiz. Dewaluacja doraźnie mogła ułatwić eksport, ale groziła podkopaniem zaufania do złotego. Spór wygrał Kwiatkowski i złoty pozostał jedną z nielicznych w Europie walut, które nie zostały zdewaluowane w latach 30 . Poza złotym były to jedynie: lit litewski, frank albański i marka niemiecka, która jednak pod rządami Hitlera stała się walutą czysto wewnętrzną i niewymienialną. Polityka gospodarcza Polski pozostała zatem bardzo ostrożna i konserwatywna. Można nawet powiedzieć, że była ona ostrożna ponad stan. Determinowane to było jednak nie tylko troską o stabilność makroekonomiczną, ale też następnym wielkim wyzwaniem, przed którym staliśmy - kapitalizacją.

\section{Kapitalizacja}

W 1914 roku polskie sfery gospodarcze dysponowały dość znaczącymi zasobami kapitału prywatnego. Dotyczyło to szczególnie zaboru rosyjskiego, który przez całe dziesięciolecia był najbardziej uprzemysłowioną częścią imperium rosyjskiego. Podczas wojny zasoby te zostały zredukowane. Ważną rolę odegrało odcięcie Królestwa Polskiego od Rosji linią frontu w 1915 roku. Powojenna inflacja dopełniła dzieła. W połowie lat 20. Polska była krajem ogołoconym z kapitałów, a polskim firmom prywatnym nie pozostał nawet cień ich dawnej świetności. Suma kapitałów własnych polskich banków akcyjnych w 1925 roku wynosiła 30\% wartości przedwojennej. W największym stopniu spadek ten dotyczył zaboru rosyjskiego, w najmniejszym - pruskiego.

W tej sytuacji najważniejszym zadaniem po osiągnięciu stabilizacji stała się odbudowa kapitału krajowego. W drugiej połowie lat 20. rozwiązanie widziano w ściągnięciu kapitałów zagranicznych. Koniunktura światowa zdawała się sprzyjać takim planom. Po przezwyciężeniu inflacji powojennych wydawało się, że powraca dawna swoboda przepływu kapitału. Zgodnie z przedwojennym modelem powinien on popłynąć z krajów rozwiniętych, gdzie występował w nadmiarze, ku krajom peryferyjnym, kuszącym wyższą stopą zysku. Reformy Władysława Grabskiego czyniły z Polski kraj otwarty na obcy kapitał, przy tym solidny i gwarantujący poczucie bezpieczeństwa. Grabski był liberałem i zwolennikiem sektora prywatnego, ale z pewnymi ograniczeniami. Uważał, że kapitał zagraniczny może zaspokoić popyt na kredyt 
krótkoterminowy. W tym zakresie wspierał banki prywatne. W założeniu miały one być kanałem, poprzez który przepływały kapitały zagraniczne. Był jednak przekonany, że kapitał zagraniczny nie zaspokoi zapotrzebowania na kapitał długoterminowy, inwestycyjny. Dlatego równolegle zbudował silny sektor bankowości państwowej. Składały się nań: Pocztowa Kasa Oszczędności (PKO), gromadząca wkłady ludności, Bank Gospodarstwa Krajowego, wspierający pożądane przez państwo inwestycje, i odrębny Państwowy Bank Rolny. W 1929 roku doszła do tego jeszcze jedna instytucja - Powszechna Kasa Opieki S.A., nastawiona na obsługę przekazów pieniężnych Polonii do kraju.

Czynnikiem komplikującym politykę ściągania do kraju kapitału zagranicznego był niechętny stosunek państwa do kapitału niemieckiego. Kapitał ten w większości znalazł się w Polsce nie na skutek własnych decyzji o inwestowaniu za granicą, lecz na skutek zmian terytorialnych. Nie bardzo można było liczyć na jego lojalność wobec państwa polskiego. Były to w ówczesnych warunkach oczywiste okoliczności, ale dyskryminacja pewnej kategorii inwestorów z przyczyn politycznych nie wyglądała dobrze. Mimo to udział kapitału zagranicznego w całości kapitałów polskich spółek akcyjnych wzrósł z 21\% w 1927 roku do 33\% w 1929 roku.

Wielki kryzys ujawnił wady takiego rozwiązania. Kapitał zagraniczny albo wycofywał się z Polski, albo wykorzystywał swoją pozycję w ten sposób, że zamykał kontrolowane przez siebie zakłady w Polsce po to, by zmniejszyć konkurencję dla produkcji w krajach macierzystych. Natomiast państwo, ratując zagrożone firmy, stawało się ich właścicielem. W ten sposób wokół BGK rósł potężny sektor państwowy, a rola kapitału państwowego wzrastała. Druga połowa lat 30. przebiegała już pod znakiem jego dominacji. Większość inwestycji w Centralnym Okręgu Przemysłowym to były inwestycje państwowe. Warto podkreślić, że stopniowa etatyzacja gospodarki nie była wyborem ideologicznym, tylko koniecznością. Eugeniusz Kwiatkowski chętnie widziałby w COP-ie kapitał prywatny, ale tego kapitału praktycznie nie było. I jeszcze jedno: w latach 30. narzekano na kapitał zagraniczny, bo unikał zaangażowania w Polsce. Pretensja o to, że „wyzyskiwał”, pojawiła się dopiero w PRL. Warto to sobie uświadomić dziś, gdy obie te pretensje w przedziwny sposób współbrzmią.

W latach 30. władze zdawały sobie sprawę z tego, że znaczne środki są zgromadzone w rękach zwykłych ludzi i tezauryzowane, czyli trzymane na czarną godzinę. Wielu ludzi miało ukryte złote carskie monety, tak zwane świnki. W Amsterdamie uruchomiono nawet produkcję ,świnek” specjalnie na rynek polski. Wydobycie tych zasobów i włączenie ich w obieg życia gospodarczego było jednym z najważniejszych zadań polityki gospodarczej. To z kolei wymagało przekonania opinii publicznej, że państwo jest stabilne, a złoty pozostanie mocną walutą ${ }^{10}$. Właśnie dlatego w 1936 roku Kwiatkowski sprzeciwił się propozycji dewaluacji.

${ }^{10}$ Dylematy te trafnie ujmuje niepublikowana dotychczas praca doktorska Jakuba Skiby: J. Skiba, Reglamentacja dewizowa w Polsce w latach 1936-1939, Szkoła Główna Handlowa, Warszawa 2016. 


\section{Modernizacja}

Modernizacja gospodarki pojmowana była jako uprzemysłowienie kraju i zmniejszenie dystansu wobec krajów wysoko rozwiniętych. W uprzemysłowieniu upatrywano też szansę na stworzenie miejsc pracy dla szybko przyrastającej liczby ludności. Taki cel był dość szeroko aprobowany. „Szeroko” nie oznaczało jednak „,powszechnie". Byli zwolennicy innej opcji. Silnemu lobby rolniczemu marzył się powrót do roli Polski jako spichlerza Europy. Za takimi pomysłami początkowo stały głównie środowiska ziemiańskie, ale z czasem też coraz bardziej popularni w kręgach ruchu ludowego zwolennicy agraryzmu. Do zasadniczej próby sił między zwolennikami industrializacji i agraryzacji kraju doszło w 1927 roku $^{11}$. Podczas przygotowań do europejskiej konferencji ekonomicznej w Genewie zarysowała się wyraźnie różnica poglądów. Plany powrotu do tradycyjnego podziału Europy na uprzemysłowiony Zachód i rolniczy Wschód były mało realne choćby dlatego, że Europa Zachodnia musiałaby, w przypadku jego przyjęcia, zamknąć się na import rolny z USA i pójść na wojnę handlową z Ameryką. W Polsce rząd, przede wszystkim za sprawą ministra przemysłu i handlu Eugeniusza Kwiatkowskiego ${ }^{12}$, opowiedział się za opcją przemysłową. W drugiej połowie lat 20. intensywnie rozbudowywano Gdynię, podjęto budowę linii kolejowej Śląsk-Gdynia, zbudowano Zakłady Azotowe w Mościskach (dziś dzielnicy Tarnowa) oraz zakłady przemysłu spożywczego i zbrojeniowego. Pojawiły się pierwsze plany uprzemysłowienia w tak zwanym trójkącie bezpieczeństwa, czyli w widłach Wisły i Sanu. Rozwijano też przemysł naftowy. W tej fazie państwo wolało raczej wspierać (poprzez ulgi podatkowe) inwestycje prywatne, niż rozbudowywać sektor państwowy. Wielki kryzys przerwał te prace na kilka lat. Kwiatkowski, który popadł w niełaskę u marszałka Piłsudskiego, nie pełnił w tym czasie funkcji rządowych. Powrócił do władzy pod koniec 1935 roku jako wicepremier i minister skarbu. Na tan czas przypadła budowa Centralnego Okręgu Przemysłowego ${ }^{13}$. O lokalizacji zadecydowały względy strategiczne - oddalenie zarówno od granicy niemieckiej, jak i radzieckiej. Nie bez znaczenia było również przeludnienie Galicji i duże ukryte bezrobocie na tamtejszej wsi. Budowa miała być realizowana w ramach planu czteroletniego (1936-1940). Tym razem głównym inwestorem miało być państwo, choć starano się przyciągnąć również kapitał prywatny. Podstawą był przemysł zbrojeniowy. W Stalowej Woli zbudowano hutę, w Mielcu i Rzeszowie

${ }^{11}$ Por. M. Ła a a, Modernizacja państwa. Polska polityka gospodarcza 1926-1929, Łódź 2002, s. 48 i n. Poglądy agrarystyczne zachowują pewną atrakcyjność do dziś. W tym kontekście warto zauważyć ich słabości. Dobre rolnictwo mogłoby zatrudnić do $10 \%$ siły roboczej. Gdyby zatrudniło więcej, nie byłoby już dobre. Agraryzm nie mógł zatem rozwiązać problemu miejsc pracy. Ponadto w obliczu zjawiska nożyc cen, które ujawniło się z całą mocą w latach wielkiego kryzysu, Polska w przypadku przyjęcia opcji agrarnej zapłaciłaby jeszcze wyższą cenę.

12 M.M. Drozdowski, Eugeniusz Kwiatkowski, Rzeszów 2005.

${ }_{13} \mathrm{Z}$ bogatej literatury na temat COP warto wyróżnić prace: W. Samecki, Centralny Okręg Przemysłowy 1936-1939. Wstępna faza programu uprzemysłowienia Polski, Wrocław 1998; M.M. Drozdowski, Polityka gospodarcza rzadu polskiego 1936-1939, Warszawa 1963; J. Gołębi ow sk i, COP. Dzieje industrializacji w rejonie bezpieczeństwa 1922-1939, Kraków 2000. 
zakłady lotnicze, w Rożnowie zaporę wodną, rozbudowano istniejący przemysł zbrojeniowy w Kielcach, Skarżysku-Kamiennej, Starachowicach czy Radomiu. Z punktu widzenia potrzeb obronności COP okazał się przedsięwzięciem spóźnionym. Ponadto w obliczu blitzkriegu przekonanie o jego bezpiecznej lokalizacji okazało się naiwne. Z punktu widzenia korzyści społecznych również nie nastąpił przełom. Wielkie zakłady wchłonęły ok. 50000 pracowników, mniejsze wraz z usługami mniej więcej drugie tyle. COP odegrał jednak ogromną rolę propagandową, porównywalną jedynie z tą, jaką w poprzedniej dekadzie pełniła budowa Gdyni. Pod koniec międzywojnia w Polsce w szerokich kręgach społeczeństwa (choć nie powszechnie) panowały optymizm i poczucie, że kraj sobie radzi. Ludzie wiedzieli, że pod wieloma względami Polska jest słabsza od krajów najbardziej rozwiniętych, ale - inaczej niż w PRL Polacy nie mieli kompleksów zacofania technologicznego. Polska myśl techniczna dorównywała światowej. Różnica ujawniała się na poziomie mniejszego potencjału produkcyjnego.

\section{Spójność społeczna i narodowościowa}

II Rzeczpospolita upadła po 20 latach istnienia. W tej sytuacji pewne jej słabości i zagrożenia z nich wynikające nie zdążyły się ujawnić w całej pełni. Dziś jednak, próbując dokonać bilansu całej epoki, powinniśmy o nich pamiętać. Słabości te widziałbym przede wszystkim w sferze spójności społecznej i narodowościowej.

Spójność społeczną można było osiągnąć, podnosząc poziom zamożności, otwierając kanały awansu społecznego i tworząc realne zaplecze dla konstytucyjnej zasady równości. Trochę na tym polu zrobiono. Szczególnie warto pamiętać o wysiłkach na rzecz upowszechnienia edukacji i ograniczenia analfabetyzmu. Było to jednak niewiele w stosunku do potrzeb. Przez całe dwudziestolecie utrzymywały się wielkie obszary biedy, a szanse wyrwania się z niej były często iluzoryczne. Najatrakcyjniejszą możliwością pozostawała emigracja. Kiepska koniunktura i brak kapitału nie pozwalały na uruchomienie mobilności społecznej, a dość powszechne określanie dobrych czasów formułą ,,jak za cara" było surową recenzją bieżącej sytuacji. Posunięciem, które mogło zmienić sytuację i którego wykonanie leżało w granicach możliwości władz polskich, byłaby reforma rolna. W tej sprawie jednak polskie władze zachowywały się bardzo powściągliwie.

Historycy gospodarczy spierają się na temat sensowności reformy. Jej przeciwnicy argumentują, że zmniejszyłaby produktywność rolnictwa ${ }^{14}$. Wielkie majątki w większym stopniu produkowały na rynek, niż robiłyby to małe gospodarstwa. Pamiętajmy jednak, że przez większość dwudziestolecia problemem była nadprodukcja artykułów rolnych, a nie ich niedobór. Natomiast wzbogacenie chłopów, które byłoby efektem reformy, poszerzyłoby rynek wewnętrzny i nakręciło koniunkturę w przemyśle. Poza tym za przeprowadzeniem reformy przemawiały względy społeczne,

${ }^{14}$ Tezę taką stawia np. W. Roszkow ski, Land Reforms in East-Central Europe after World War One, Warszawa 1995. 
przede wszystkim realne zrównanie szans i przełamanie zakorzenionych w świadomości barier stanowych. O ostrożności władz w tej dziedzinie decydowały jednak obawy przez brakiem spójności w innej sferze - narodowościowej.

Pierwszą, dość radykalną wersję reformy rolnej uchwalono latem 1920 roku w obliczu zagrożenia państwa, kiedy trzeba było zneutralizować propagandę bolszewicką skierowaną do chłopów. Jednak jesienią tego roku okazało się, że Polska nie tylko nie przegrała wojny, ale zdobyła Kresy Wschodnie. A tam reforma rolna oznaczała przechodzenie ziemi z rąk polskich w ręce ukraińskie i białoruskie. Dlatego prawica przeforsowała ustawę o osadnictwie wojskowym. Pierwszeństwo w otrzymaniu ziemi na Wschodzie mieli odtąd nie okoliczni chłopi, ale zasłużeni żołnierze. Rozwiązanie to narobiło na kresach Wschodnich mnóstwo złego. W 1921 roku, po uchwaleniu konstytucji marcowej, okazało się, że reforma z 1920 roku jest z nią sprzeczna, nie przewiduje bowiem pełnego odszkodowania. Ostateczną, bardzo łagodną wersję reformy przyjęto w 1925 roku. Główny problem: z jednej strony wielka własność ziemska, z drugiej biedna i przeludniona wieś - pozostał nierozwiązany. Kluczową rolę w wyborze tej drogi odegrała obawa przed skurczeniem się polskiego stanu posiadania na Kresach. W ten sposób brak spójności narodowościowej przekładał się na niemoc w dziedzinie przezwyciężenia braku spójności społecznej.

\section{PODSUMOWANIE}

Krótka historia II Rzeczypospolitej zakończyła się klęską militarną, poniesioną jednak w słusznej sprawie. Potem przez długi czas II RP była oczerniana przez władze PRL, których legitymacja do przewodzenia narodowi i ferowania wyroków moralnych była wątpliwej jakości. Taka sytuacja nie sprzyjała rzetelnym rozliczeniom z przeszłością. Wręcz przeciwnie, sprzyjała idealizacji i utrwalała mit, który u schyłku PRL stał się dominujący.

Mit ten częściowo znajduje pokrycie w rzeczywistości. W stosunkowo krótkim czasie przezwyciężono poważne problemy, dokonano znaczącego kroku na drodze modernizacji, w warunkach niesprzyjającej koniunktury stworzono przyczółki nowoczesności. Jednak wyobrażenie o Polsce międzywojennej jako o kraju, który szedł ku świetlanej przyszłości i tylko wybuch wojny przekreślił te nadzieje, jest naiwne. Skala napięć narodowościowych była tak duża, że nawet znacznie szybsza modernizacja nie zdołałaby ich zneutralizować. 


\section{BIBLIOGRAFIA}

Drozdow ski M.M., Eugeniusz Kwiatkowski, Rzeszów 2005.

Drozdow s ki M.M., Polityka gospodarcza rzadu polskiego 1936-1939, Warszawa 1963.

Gołębiows ki J., COP. Dzieje industrializacji w rejonie bezpieczeństwa 1922-1939, Kraków 2000.

Grat a P., Polityka społeczna Drugiej Rzeczypospolitej, Rzeszów 2013.

Knakiewicz Z., Deflacja polska 1930-1935, Warszawa 1967.

L and a u Z., Plan stabilizacyjny 1927-1930, Geneza, założenia, wyniki, Warszawa 1963.

Landau Z., Tomaszewski J., Gospodarka Polski międzywojennej, t. I-IV, Warszawa 1967-1989.

Leszczyńska C., Polska polityka pieniężna i walutowa $w$ latach 1924-1936 w systemie Gold Exchange Standard, Warszawa 2013.

Ła p M., Modernizacja państwa. Polska polityka gospodarcza 1926-1929, Łódź 2002.

Moraw ski W., Od marki do złotego. Historia finansów Drugiej Rzeczypospolitej, Warszawa 2008.

Moraw ski W., Polityka gospodarcza rządu Aleksandra Skrzyńskiego, Warszawa 1990.

Od Grabskiego do Balcerowicza. Systemy pieniężne w gospodarce polskiej, red. S. Kow al, Poznań 1997.

Problemy gospodarcze Drugiej Rzeczypospolitej, red. I. K o strow i k a, Warszawa 1989.

Roszkowski W., Land Reforms in East-Central Europe after World War One, Warszawa 1995.

S a m e c ki W., Centralny Okreg Przemysłowy 1936-1939. Wstęna faza programu uprzemysłowienia Polski, Wrocław 1998.

S kib a J., Reglamentacja dewizowa w Polsce w latach 1936-1939, mps pracy doktorskiej, Szkoła Główna Handlowa, Warszawa 2016.

To mas zew ski J., Stabilizacja waluty w Polsce. Z badań nad polityka gospodarcza rzadu polskiego przed zamachem majowym, Warszawa 1961. 